\title{
PENERAPAN DIGITAL SIGNATURE SCHEME DENGAN METODE SCHNORR AUTHENTICATION
}

\author{
Erfan Wahyudi ${ }^{1}$, Muhammad Masjun Efendi ${ }^{2}$, Moh. Subli ${ }^{3}$, Ahmad Subki ${ }^{4}$, Muhamad Rijal Alfian ${ }^{5}$ \\ Universitas Teknologi Mataram ${ }^{1,2,3,4,5}$ \\ erfan.wahyudie@gmail.com
}

\begin{abstract}
Abstrak - Otentikasi (authentication) merupakan identifikasi yang dilakukan oleh masing-masing pihak yang saling berkomunikasi, maksudnya beberapa pihak yang berkomunikasi harus mengidentifikasi satu sama lainnya. Informasi yang didapatkan oleh satu pihak dari pihak lain harus diidentifikasi untuk memastikan keaslian informasi yang diterima. Tanda tangan digital adalah suatu mekanisme otentikasi yang memungkinkan pembuat pesan menambahkan sebuah kode yang bertindak sebagai tanda tangannya. Skema yang dapat digunakan untuk melakukan proses tanda tangan digital terhadap suatu pesan juga bermacam-macam. Skema otentikasi dan tanda tangan digital Schnorr merupakan skema tanda tangan digital yang mengambil keamanan dari permasalahan menghitung logaritma diskrit. Masalah pertama, membuktikan keaslian dokumen, dapat dilakukan dengan teknologi pemberian cap air dan tanda tangan digital. Pemberian cap air juga dapat digunakan untuk menjaga hak milik intelektualitas, yaitu dengan menandai dokumen atau hasil karya dengan "tanda tangan" pembuat. Masalah kedua biasanya berhubungan dengan akses kontrol, yaitu berkaitan dengan pembatasan orang yang dapat mengakses informasi. Dalam hal ini pengguna harus menunjukkan bukti bahwa memang dia adalah pengguna yang sah, misalnya dengan menggunakan kata sandi aspek/servis dari security biometric (ciri-ciri khas orang), dan sejenisnya. Dalam penelitian ini melakukan simulasi otentikasi digital signature dengan menerapkan metode hash SHA 1, tanda tangan digital tidak mudah untuk di kelabui.
\end{abstract}

Kata kunci: Authentication, Digital Signature, Encryption

\section{Latar Belakang}

Simulasi sebagai proses pengolahan data dengan penggunaan rangkaian modelsimbolik pada pengoperasian sistem tiruan tidak mengharuskan dan tidak mengajukan penggunaan fungsi-fungsi dan persamaan tertentu sebagai model simbolik penyelesaian persoalan, tetapi sebaliknya simulasi yang terdiri dari tahapan-tahapan dan langkahlangkah pengolahan data haruslah dilengkapi dengan model-model simbolik yang sesuai dengan memberikan hasil pengoperasian tiruan dalam bentuk data output yang berguna untuk penyelesaian persoalan.

Sesuai dengan bentuk simulasi yang terdiri dari tahapan dan langkah - langkah pengolahan data, aplikasi simulasi untuk setiap persoalan haruslah berdasarkan pemodelan untuk persoalan yang perlu diselesaikan. Simulasi bersifat terbuka dan dapat digunakan untuk penyelesaian berbagai bentuk persoalan sistem yang sesuai dengan berbagai bidang, namun kegunaannya relatif tergantung pada kelayakan serta manfaat dari hasil simulasi yang diperoleh pada penyelesaian persoalan yang berlatar belakang sistem.

Otentikasi (authentication) merupakan identifikasi yang dilakukan oleh masing - masing pihak yang saling berkomunikasi, maksudnya beberapa pihak yang berkomunikasi harus mengidentifikasi satu sama lainnya. Informasi yang didapat oleh suatu pihak dari pihak lain harus diidentifikasi untuk memastikan keaslian dari informasi yang diterima. Identifikasi terhadap suatu informasi dapat berupa tanggal pembuatan informasi, isi informasi, waktu kirim dan hal-hal lainnya yang berhubungan dengan informasi tersebut. Otentikasi pesan memang berhasil melindungi kedua belah pihak yang saling bertukar pesan dari pihak ketiga. Tetapi, otentikasi pesan tidak bisa mencegah kemungkinan kedua belah pihak saling menyerang satu sama lain. Pada situasi dimana tidak ada kepercayaan penuh antara pengirim dan penerima pesan, diperlukan suatu mekanisme yang lebih daripada sekedar otentikasi. Solusi yang paling menarik dari masalah ini adalah tanda tangan digital (digital signature). Tanda tangan digital adalah suatu mekanisme otentikasi yang memungkinkan

Penerapan Digital Signature Scheme Dengan Metode Schnorr Authentication 
pembuat pesan menambahkan sebuah kode yang bertindak sebagai tanda tangannya. Tanda tangan tersebut menjamin integritas dan sumber dari sebuah pesan.

Claus Schnorr's authentication dan digital signature scheme mengambil sekuritas dari permasalahan menghitung logaritma diskrit. Skema ini menggunakan bilangan prima dan perpangkatan modulo dalam proses pembentukan kuncinya. Skema ini dipatenkan di Amerika Serikat dan akan berakhir pada tanggal 19 Pebruari 2008. Skema otentikasi dapat dimodifikasi menjadi skema tanda tanda digital (digital signature scheme). Proses pembentukan kunci privat dan publiknya sama seperti skema otentikasi, hanya saja pada skema tanda tangan digital ditambahkan sebuah fungsi hash.

\section{Kajian Teori}

\subsection{Keamanan Informasi}

Keamanan informasi (information security) merupakan perlindungan terhadap informasi ketika informasi dikirim dari sebuah sistem ke sistem lainnya. Sistem kemanan informasi memiliki empat tujuan yang sangat mendasar, yaitu:

1. Confidentiality

Menjamin apakah informasi yang dikirim tersebut tidak dapat dibuka atau tidak dapat diketahui oleh orang lain yang tidak berhak. Untuk data yang penting, dibutuhkan sekali tingkat kerahasiaan yang tinggi, yang hanya bisa diakses oleh pihak-pihak tertentu saja (pihak yang berhak).

2. Integrity

Menjamin keutuhan dan keaslian data, sehingga upaya pihak-pihak yang tidak bertanggung jawab untuk melakukan penduplikatan dan perusakan data dapat dihindari.

3. Availability

Menjamin pengguna yang sah agar dapat mengakses informasi dan sumber miliknya sendiri. Tujuannya adalah untuk memastikan bahwa pihak-pihak yang memang berhak tidak ditolak untuk mengakses informasi yang memang menjadi haknya.

4. Legitimate Use

Menjamin kepastian bahwa sumber tidak digunakan atau informasi tidak diakses oleh pihak-pihak yang tidak bertanggung jawab (pihak-pihak yang tidak berhak).

\section{$2.2 \quad$ Kriptografi}

Cryptography adalah ilmu yang mempelajari teknik-teknik matematika yang berhubungan dengan aspek-aspek pada keamanan informasi misalnya kerahasiaan, integritas data, otentikasi pengirim / penerima data, dan otentikasi data. Cryptography (kriptografi) berasal dari bahasa Yunani yaitu dari kata 'cryptos' dan 'graphia' yang berarti penulisan rahasia. Kriptografi adalah suatu ilmu yang mempelajari penulisan secara rahasia. Kriptografi bertujuan menjaga kerahasiaan informasi yang terkandung dalam data sehingga informasi tersebut tidak dapat diketahui oleh pihak yang tidak sah.

Suatu pesan yang tidak disandikan disebut sebagai plaintext ataupun dapat disebut juga sebagai cleartext. Proses yang dilakukan untuk mengubah plaintext ke dalam ciphertext disebut encryption atau encipherment. Sedangkan proses untuk mengubah ciphertext kembali ke plaintext disebut decryption atau decipherment.

Secara sederhana, konsep umum kriptografi dapat dilihat pada gambar 2.1 berikut.

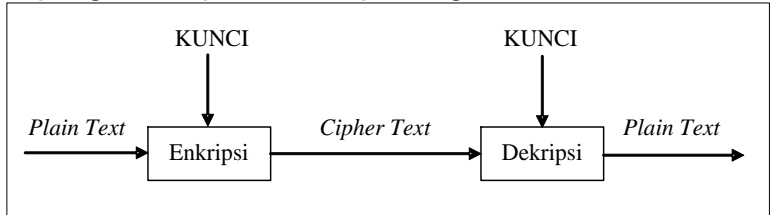

Gambar 2.1 Gambaran umum proses kriptografi

Cryptography merupakan suatu ilmu atau seni mengamankan pesan yang dilakukan oleh seorang cryptographer. Sedangkan cryptanalysis adalah suatu ilmu dan seni membuka (breaking) ciphertext dan orang yang melakukannya disebut cryptanalyst.

Cryptographic system atau cryptosystem adalah suatu fasilitas untuk mengkonversikan plaintext ke ciphertext dan sebaliknya. Dalam sistem ini, seperangkat parameter yang menentukan transformasi pen-cipher-an tertentu disebut suatu set kunci. Proses enkripsi dan dekripsi diatur oleh satu atau beberapa kunci kriptografi. Secara umum, kunci-kunci yang digunakan untuk proses pengenkripsian dan pendekripsian tidak perlu identik, tergantung pada sistem yang digunakan.

Secara umum operasi enkripsi dan dekripsi dapat diterangkan secara matematis sebagai berikut :

$$
\begin{aligned}
& \text { EK }(M)=C \quad \text { (Proses Enkripsi) } \\
& \text { DK }(C)=M \quad \text { (Proses Dekripsi) }
\end{aligned}
$$

Pada saat proses enkripsi, pesan $M$ (message) disandikan dengan suatu kunci $\mathrm{K}$ (key), sehingga dihasilkan pesan $\mathrm{C}$ (ciphertext). Pesan $\mathrm{C}$ adalah pesan terenkripsi dan tidak dapat dibaca. Dalam hal ini, $C$ berfungsi sebagai sandi rahasia yang hanya dapat dibaca oleh pihak-pihak yang berhak. Sedangkan pada proses dekripsi,

Penerapan Digital Signature Scheme Dengan Metode Schnorr Authentication 
pesan $\mathrm{C}$ tersebut disandikan kembali dengan menggunakan kunci $\mathrm{K}$ sehingga dihasilkan pesan $M$ yang sama seperti pesan sebelumnya.

Dengan demikian, keamanan suatu pesan tergantung pada kunci yang digunakan dan tidak tergantung pada algoritma yang digunakan. Sehingga algoritma-algoritma yang digunakan tersebut dapat dipublikasikan dan dianalisis, serta produk-produk yang menggunakan algoritma tersebut dapat diproduksi massal. Tidak menjadi masalah apabila seseorang mengetahui algoritma yang kita gunakan. Selama ia tidak mengetahui kunci yang dipakai, ia tetap tidak dapat membaca pesan.

\subsection{Fungsi One-Way Hash SHA-1}

Sebuah fungsi hash (hash function atau hash algorithm) adalah suatu cara untuk menghasilkan sebuah digital "fingerprint" kecil dari sembarang data. Fungsi ini memecahkan dan mencampurkan data untuk menghasilkan fingerprint yang sering disebut sebagai nilai hash (hash value). Nilai hash ini sering direpresentasikan dengan sebuah string pendek dari huruf-huruf dan angka-angka yang kelihatan acak (berbentuk heksadesimal). Sebuah fungsi hash yang baik adalah suatu fungsi yang tidak (jarang) memiliki output nilai hash yang sama untuk input yang berbeda.

Secure Hash Algorithm, SHA-1 ini dikembangkan oleh NIST (National Institute of Standard and Technology). SHA-1 dapat diterapkan dalam penggunaan Digital Signature Algorithm (DSA) yang dispesifikasikan dalam Digital Signature Standard (DSS) dan SHA tersebut dapat diterapkan untuk aplikasi federal.

Untuk suatu pesan yang panjangnya < $2^{64}$, SHA-1 akan menghasilkan keluaran sebanyak 160 bit dari pesan tersebut dan pesan keluaran itu disebut message digest. Panjang jarak message digest dapat berkisar antara 160 sampai 512 bit tergantung algoritmanya. Berdasarkan cirinya SHA-1 dapat digunakan dengan algoritma kriptografi lainnya seperti Digital Signature Algorithms atau dalam generasi angka yang acak (bits).

SHA-1 dikatakan aman karena proses SHA-1 dihitung secara infisibel untuk mencari pesan yang sesuai untuk menghasilkan message digest atau dapat juga digunakan untuk mencari dua pesan yang berbeda yang akan menghasilkan message digest yang sama.

Menurut jenisnya SHA dapat dispesifikasikan menjadi 4 bagian yaitu: SHA-1, SHA-256, SHA-384, dan SHA-512. Berikut ini merupakan daftar-daftar properti dari keempat SHA.

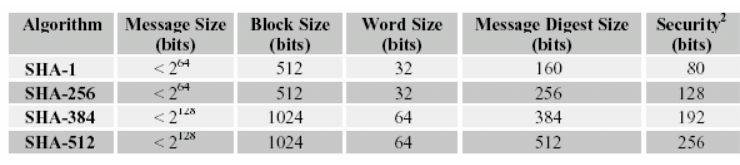

Gambar 2.2 Daftar-daftar properti dari keempat SHA

Untuk SHA-1 ukuran blok pesan -m bitdapat ditentukan tergantung dari algoritmanya. Pada SHA-1 masing-masing blok pesan mempunyai 512 bit dimana dapat dilakukan dengan 16 urutan sebesar 32 bit.

SHA-1 digunakan untuk menghitung message digest pada pesan atau file data yang diberikan sebagai input. Tujuan pengisian pesan adalah untuk menghasilkan total dari pesan yang diisi menjadi perkalian dari 512 bits.

\subsection{Authentication dan Digital Signature \\ 2.4.1 Authentication}

Otentikasi (authentication) merupakan sebuah istilah yang digunakan dalam pengertian yang luas. Secara tersirat kata tersebut mempunyai arti lebih dari sekedar menyampaikan ide yaitu bahwa alat tersebut telah menyediakan jaminan bahwa informasi tidak dimanipulasi oleh pihak yang tidak mempunyai wewenang. Otentikasi bersifat spesifik dalam topik keamanan yang berusaha dicapai. Contohnya meliputi pengendalian akses, otentikasi entity, otentikasi pesan, integritas data, non-repudiation, dan otentikasi kunci.

Otentikasi merupakan salah satu hal yang paling penting dalam keamanan informasi. Hingga pertengahan tahun 1970-an, dipercaya bahwa kerahasiaan dan otentikasi terhubung secara erat. Dengan penemuan dari fungsi-fungsi hash dan digital signatures, disadari bahwa kerahasiaan dan otentikasi sebenarnya adalah masalah yang terpisah dan independen. Awalnya tidak kelihatan penting untuk memisahkan keduanya tetapi terdapat situasi dimana hal tersebut tidak hanya berguna tetapi juga penting. Contohnya, jika terdapat komunikasi dua pihak antara Anto dan Badu yang berlangsung, dimana Anto berada di suatu negara dan Badu di negara lainnya, Negara tuan rumah mungkin tidak memperbolehkan kerahasiaan dalam saluran komunikasi karena satu atau kedua negara mungkin ingin memonitor semua komunikasi. Namun, Anto dan Badu ingin meyakinkan identitas masing-masing, dan juga integritas serta keaslian dari informasi yang mereka kirim dan mereka terima.

Skenario diatas menggambarkan beberapa aspek otentikasi yang independen. Jika Anto dan Badu ingin meyakinkan identitas masing-masing, terdapat dua kemungkinan yang dapat dipertimbangkan. 
1. Anto dan Badu dapat berkomunikasi tanpa penundaan waktu. Berarti mereka berkomunikasi secara real time.

2. Anto atau Badu dapat saling menukar pesan dengan penundaan waktu. Berarti pesan mungkin di-routing melalui jaringan yang berbeda, disimpan, dan disampaikan pada beberapa saat kemudian.

Dalam kemungkinan pertama, Anto dan Badu akan memverifikasi identitas masing-masing secara real time. Hal ini dapat dicapai oleh Anto dengan mengirimkan beberapa challenge kepada Badu dimana hanya Badu yang dapat meresponnya secara tepat. Badu dapat melakukan tindakan yang sama untuk mengidentifikasi Anto. Jenis otentikasi ini secara umum dikenal sebagai otentikasi entity atau secara sederhana disebut identifikasi.

Dalam kemungkinan kedua, tidaklah tepat untuk mengirimkan challenge dan menunggu respon, dan selain itu jalur komunikasi mungkin hanya tersedia pada satu arah. Teknik yang berbeda sekarang diperlukan untuk mengotentikasi keaslian pesan. Bentuk otentikasi ini disebut otentikasi keaslian data (data origin authentication).

\subsubsection{Digital Signature}

Tanda tangan digital adalah suatu mekanisme otentikasi yang memungkinkan pembuat pesan menambahkan sebuah kode yang bertindak sebagai tanda tangannya. Tanda tangan tersebut menjamin integritas dan sumber dari sebuah pesan.

Penandatanganan digital terhadap suatu dokumen adalah sidik jari dari dokumen tersebut beserta timestamp-nya dienkripsi dengan menggunakan kunci privat pihak yang menandatangani. Tanda tangan digital memanfaatkan fungsi hash satu arah untuk menjamin bahwa tanda tangan itu hanya berlaku untuk dokumen yang bersangkutan saja. Keabsahan tanda tangan digital itu dapat diperiksa oleh pihak yang menerima pesan.

Sifat yang diinginkan dari tanda tangan digital diantaranya adalah :

1 Tanda tangan itu asli (otentik), tidak mudah ditulis / ditiru oleh orang lain. Pesan dan tanda tangan pesan tersebut juga dapat menjadi barang bukti, sehingga penandatangan tak bisa menyangkal bahwa dulu ia pernah menandatanganinya.

2 Tanda tangan itu hanya sah untuk dokumen (pesan) itu saja. Tanda tangan itu tidak bisa dipindahkan dari suatu dokumen ke dokumen lainnya. Ini juga berarti bahwa jika dokumen itu diubah, maka tanda tangan digital dari pesan tersebut tidak lagi sah.

3 Tanda tangan itu dapat diperiksa dengan mudah.

4 Tanda tangan itu dapat diperiksa oleh pihakpihak yang belum pernah bertemu dengan penandatangan.

5 Tanda tangan itu juga sah untuk copy dari dokumen yang sama persis.

\subsection{Schnorr Authentication and Digital Signature Scheme \\ Claus Schnorr Authentication dan Digital} Signature scheme mengambil sekuritas dari permasalahan menghitung logaritma diskrit. Skema ini juga menggunakan bilangan prima dan perpangkatan modulo dalam proses pembentukan kuncinya. Tingkat kesulitan untuk memecahkan algoritma ini adalah sekitar $2^{t}$, dimana nilai $t$ ini dapat ditentukan sendiri.

Skema ini dipatenkan di Amerika Serikat dan akan berakhir pada tanggal 19 Pebruari 2008. Skema otentikasi dapat dimodifikasi menjadi skema tanda tanda digital (digital signature scheme). Proses pembentukan kunci privat dan publiknya sama seperti skema otentikasi, hanya saja pada skema tanda tangan digital ditambahkan sebuah fungsi hash.

\section{Perancangan Sistem}

Perangkat lunak simulasi ini diawali dari form Utama yang berisi pilihan atau link ke form Pembentukan Kunci, form Skema Otentikasi, form Skema Tanda Tangan Digital, form Teori dan form About. Form Pembentukan Kunci mensimulasikan dan menjelaskan proses kerja pembentukan kunci. Dalam proses ini, dihasilkan dua buah kunci, yaitu $s$ (kunci privat) dan $v$ (kunci publik) yang akan digunakan pada proses otentikasi dan tanda tangan digital. Form Skema Otentikasi mensimulasikan dan menjelaskan prosedur kerja dari skema otentikasi. Dalam skema otentikasi, algoritma proses otentikasi dijelaskan secara bertahap. Form Skema Tanda Tangan Digital mensimulasikan dan menjelaskan prosedur kerja dari skema tanda tangan digital. Dalam skema ini, pesan yang akan dikirimkan, dibubuhi dengan tanda tangan digital terlebih dahulu. Tanda tangan digital akan dikirimkan bersamaan dengan pesan sebagai jaminan bahwa pesan tersebut adalah asli dan utuh.

Semua nilai variabel pada proses pembentukan kunci, otentikasi dan tanda tangan digital dapat diinput sendiri ataupun dihasilkan secara acak oleh komputer. Perangkat lunak juga memiliki form Teori, yang menyediakan teori-teori lebih lanjut mengenai skema Schnorr dan form About 
berfungsi untuk menampilkan informasi yang mengenai pembuat perangkat lunak. Alur kerja perangkat lunak digambarkan di dalam bentuk State Transition Diagram (STD) seperti terlihat pada gambar 3.1 berikut.

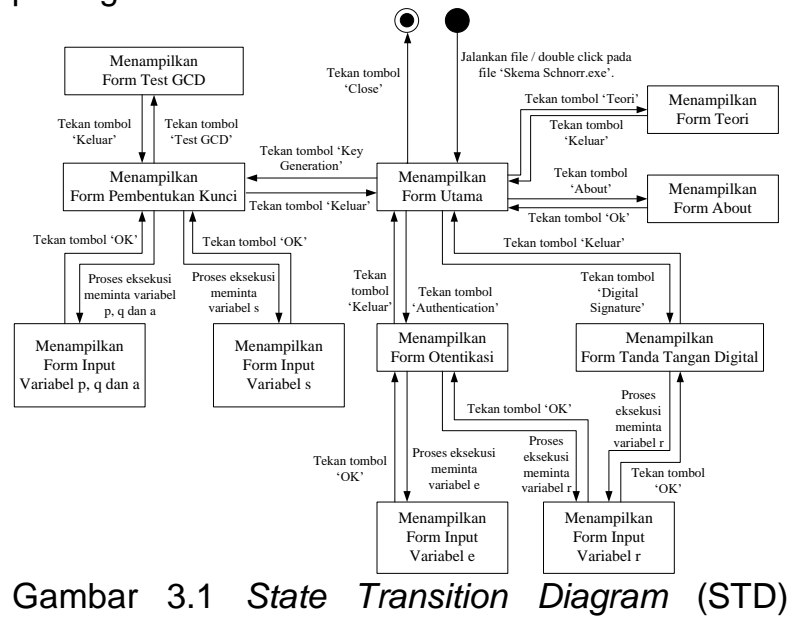
Perangkat Lunak

4. Hasil Penelitian

\subsection{Algoritma}

Secara umum, algoritma yang digunakan untuk merancang perangkat lunak simulasi Schnorr Authentication dan Digital Signature Scheme adalah:

1. Algoritma pembentukan kunci.

2. Algoritma skema otentikasi.

3. Algoritma skema tanda tangan digital.

4. Algoritma tes prima Rabin Miller.

5. Algoritma Fast Exponentiation.

6. Algoritma Greatest Common Divisor (GCD).

7. Algoritma Extended Euclidean.

\subsubsection{Algoritma Pembentukan Kunci}

Proses pembentukan kunci merupakan proses awal sebelum melakukan proses otentikasi ataupun proses tanda tangan digital. Proses pembentukan kunci menghasilkan dua buah kunci, yaitu s (kunci privat) dan v (kunci publik) yang akan digunakan pada skema otentikasi dan tanda tangan digital. Kunci privat adalah kunci yang dipegang oleh pihak pertama (Alice atau pembuat skema), sedangkan kunci publik diberikan kepada pihak kedua (Bob atau pihak lain yang berinteraksi dengan Alice).

Algoritma pembentukan kunci adalah sebagai berikut:

1. Pilih dua buah bilangan prima $p$ dan $q$, dan sebuah nilai a, dimana GCD(q, p-1) $<1$ dan $\left(a^{\wedge} q\right) \bmod p=1$.

a. $\operatorname{GCD}(q, p-1)<>1$ artinya nilai variabel $q$ dan $(p-1)$ tidak relatif prima. Dengan kata lain, kedua variabel tersebut memiliki minimal satu faktor prima yang sama. Algoritma GCD dapat dilihat pada subbab 4.1.6.

b. Operasi perpangkatan modulo $\left(a^{\wedge} q\right)$ $\bmod p=1$ menggunakan algoritma Fast Exponentiation. Algoritma Fast Exponentiation digunakan untuk menghindari output nilai yang melebihi batas maksimum (overflow) dari tipe variabel angka. Dengan perhitungan biasa, overflow sering terjadi apabila nilai q sangat besar. Algoritma Fast Exponentiation dapat dilihat pada subbab 4.1.5.

2. Pilih sebuah nilai $s$, dimana $s$ harus lebih kecil dari q. Nilai $s$ adalah kunci privat dan tidak boleh diketahui oleh pihak lain.

3. Hitung nilai $v$ dengan rumus: $v=a^{\wedge}(-s) \bmod p$. Operasi ini diturunkan menjadi:

$$
\begin{aligned}
& v=\left(a^{\wedge}(-1)\right)^{\wedge} s \bmod p \\
& v=\left(a^{\wedge}(-1)\right)^{\wedge} s \bmod p \\
& v=\left(a^{\wedge}(-1) \bmod p\right)^{\wedge} s \bmod p
\end{aligned}
$$

a. Operasi $\left(a^{\wedge}(-1) \bmod p\right)$ diselesaikan dengan menggunakan algoritma Extended Euclidean. Algoritma Extended Euclidean dapat dilihat pada subbab 4.1.7.

b. Selanjutnya (operasi pada poin a) dipangkat dengan $s$ modulo $p$ diselesaikan dengan menggunakan algoritma Fast Exponentiation.

c. Hasil dari poin $b$ adalah nilai $v$ yang digunakan sebagai kunci publik. Kunci publik diberikan kepada pihak yang akan berinteraksi dengan pihak pertama (Alice) baik dalam skema otentikasi maupun skema tanda tangan digital.

\subsubsection{Algoritma Skema Otentikasi}

Skema otentikasi digunakan apabila salah satu pihak dalam saluran komunikasi ingin memverifikasi keaslian (otentikasi) dari pihak lainnya. Algoritma skema otentikasi adalah sebagai berikut:

1. Alice memilih sebuah nilai $r$, dimana nilai $r$ lebih kecil dari q.

2. Alice menghitung: $x=\left(a^{\wedge} r\right)$ mod $p$ dan mengirimkan $x$ kepada Bob.

Operasi $\left(a^{\wedge} r\right) \bmod p$ diselesaikan dengan menggunakan algoritma Fast Exponentiation.

3. Bob memilih sebuah nilai e yang berada di antara nilai 0 sampai $\left(2^{t}-1\right)$ dan mengirimkan e kepada Alice. Nilai t merupakan parameter kemanan yang dimiliki oleh Bob. Oleh karena itu disarankan agar $t$ bernilai besar. 
4. Alice menghitung: $y=\left(r+\left(s^{*} e\right)\right)$ mod $q$ dan mengirimkan y kepada Bob. Operasi ini diselesaikan dengan operasi aritmatika biasa.

5. Bob melakukan verifikasi: $x=\left(\left(a^{\wedge} y\right) \cdot\left(v^{\wedge} e\right)\right)$ mod p. Oleh karena, operasi $\left(\left(a^{\wedge} y\right) \cdot\left(v^{\wedge} e\right)\right)$ dapat menghasilkan nilai yang overflow, maka operasi untuk menghasilkan nilai $\mathrm{x}$ dapat diturunkan menjadi:

$$
x=\left(\left(\left(a^{\wedge} y\right) \bmod p\right) \cdot\left(\left(v^{\wedge} e\right) \bmod p\right)\right) \bmod p
$$
Masing-masing operasi $\left(\left(a^{\wedge} y\right)\right.$ mod $\left.p\right)$ dan $\left(\left(v^{\wedge} e\right) \bmod p\right)$ diselesaikan dengan menggunakan algoritma Fast Exponentiation. Jika nilai $x$ sesuai atau sama dengan nilai hasil operasi, maka verifikasi berhasil. Jika tidak, maka verifikasi gagal.

\subsubsection{Algoritma Skema Tanda Tangan Digital}

Skema tanda tangan digital (digital signature) digunakan untuk menjaga keaslian dan keutuhan dari pesan yang akan dikirimkan. Pengubahan atau penghapusan terhadap satu bagian atau lebih dari pesan asli akan mengakibatkan verifikasi tanda tangan digital menjadi tidak benar. Pada skema ini, tanda tangan digital disertakan dalam pesan yang akan dikirimkan melalui suatu saluran komunikasi.

Algoritma skema tanda tangan digital adalah sebagai berikut:

1. Alice memilih sebuah nilai $r$, dimana nilai $r$ lebih kecil dari q dan menghitung menghitung: $x=\left(a^{\wedge} r\right) \bmod p$. Operasi ini diselesaikan dengan menggunakan algoritma Fast Exponentiation.

2. Alice menggabungkan (concatenate) $M$ dan $x$ dan menghitung nilai hash dari hasil penggabungan tersebut: $\mathrm{e}=\mathrm{H}(\mathrm{M}, \mathrm{x})$.

a. $\mathrm{M}$ adalah kode ascii dari setiap huruf di dalam pesan, sehingga banyak variabel e adalah sebesar jumlah huruf di dalam pesan.

b. Hasil penggabungan $M$ dengan $x$ dimasukkan ke fungsi hash SHA-1. Kemudian, ambil 4 karakter dari output fungsi hash dan ubah setiap karakter menjadi nilai ascii. Penggabungan nilai ascii dari setiap karakter adalah hasil fungsi hash yang disimpan di variabel e.

3. Alice menghitung: $y=(r+s . e)$ mod $q$.

a. Karena variabel e berbentuk array dengan jumlah array sebesar jumlah huruf di dalam pesan, maka variabel y juga berbentuk array dengan jumlah array sebesar ukuran array dari variabel e.

b. Tanda tangan digital dari pesan adalah e dan y. Format tanda tangan di dalam perangkat lunak disusun dalam format: " $\left|\mathrm{e}_{1}, \mathrm{y}_{1}\right| \mathrm{e}_{2}, \mathrm{y}_{2} \mid \mathrm{e}_{3}, \mathrm{y}_{3} \ldots .$.

4. Bob menghitung: $x^{\prime}=\left(\left(a^{\wedge} y\right) \cdot\left(v^{\wedge} e\right)\right) \bmod p$. Oleh karena, operasi $\left(\left(a^{\wedge} y\right) \cdot\left(v^{\wedge} e\right)\right)$ dapat menghasilkan nilai yang overflow, maka operasi untuk menghasilkan nilai $x^{\prime}$ dapat diturunkan menjadi:

$x^{\prime}=\left(\left(\left(a^{\wedge} y\right) \bmod p\right) \cdot\left(\left(v^{\wedge} e\right) \bmod p\right)\right) \bmod p$ Masing-masing operasi $\left(\left(a^{\wedge} y\right) \bmod p\right)$ dan $\left(\left(v^{\wedge} e\right) \bmod p\right)$ diselesaikan dengan menggunakan algoritma Fast Exponentiation.

Bob menggabungkan $M$ dan $x^{\prime}$ dan melakukan verifikasi: $\mathrm{e}=\mathrm{H}\left(\mathrm{M}, \mathrm{x}^{\prime}\right)$. Operasi ini sama dengan operasi yang telah dijelaskan pada poin 2 , perbedaannya hanya terletak pada penggunaan variabel $x$ ' dan $x$. Jika nilai e sesuai atau sama dengan nilai hash, maka verifikasi tanda tangan digital berhasil. Jika salah satu nilai e tidak sesuai, maka verifikasi tanda tangan digital akan gagal.

\subsubsection{Pengujian Program}

Untuk menguji output program, pengujian akan dilakukan pada proses pembentukan kunci (key generation), proses otentikasi (authentication) dan proses tanda tangan digital (digital signature).

\section{Proses Pembentukan Kunci}

Form proses pembentukan kunci dapat dilihat pada gambar 4.1 berikut.

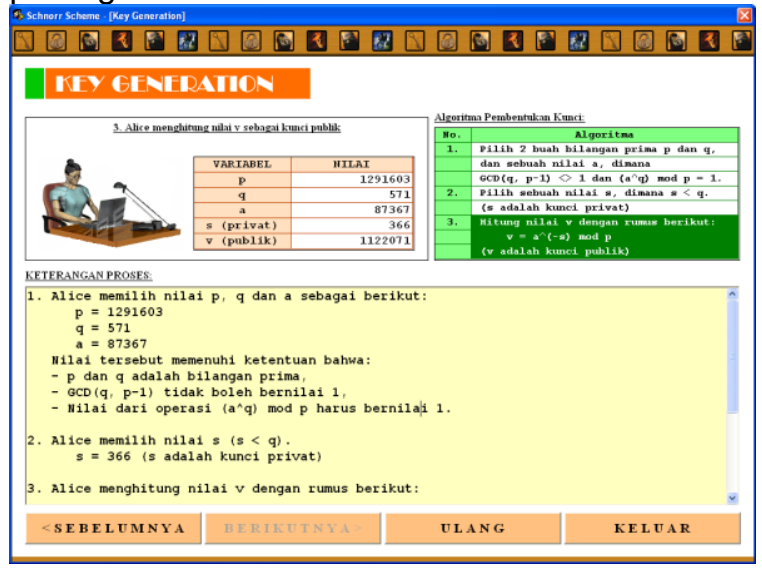

Gambar 4.1 Form Proses Pembentukan Kunci

Prosedur yang dilakukan pada proses pembentukan kunci adalah sebagai berikut:

1. Alice memilih nilai $p, q$ dan a sebagai berikut:

$p=1291603$

$q=571$

Penerapan Digital Signature Scheme Dengan Metode Schnorr Authentication 
$a=87367$

Nilai tersebut memenuhi ketentuan bahwa:

- $p$ dan $q$ adalah bilangan prima,

- GCD(q, p-1) tidak boleh bernilai 1,

- Nilai dari operasi $\left(a^{\wedge} q\right) \bmod p$ harus bernilai 1.

2. Alice memilih nilai $s(s<q)$.

$\mathrm{s}=366$ (s adalah kunci privat)

3. Alice menghitung nilai $v$ dengan rumus berikut:

$v=a^{\wedge}(-s) \bmod p$

$v=87367^{\wedge}(-366) \bmod 1291603$

$v=\left(\left(87367^{\wedge}(-1) \bmod 1291603\right)^{\wedge} 366\right) \bmod$ 1291603

Selesaikan operasi $\left(87367^{\wedge}(-1) \bmod 1291603\right)$ dengan

algoritma extended euclidean

$\left(87367^{\wedge}(-1) \bmod 1291603\right)=1253269$

$v=\left(1253269^{\wedge} 366\right) \bmod 1291603$ (selesaikan dengan fast exponentiation)

$v=1122071$ ( $v$ adalah kunci publik)

\section{Proses Otentikasi (Authentication)}

Form proses otentikasi dapat dilihat pada gambar 4.2 berikut.

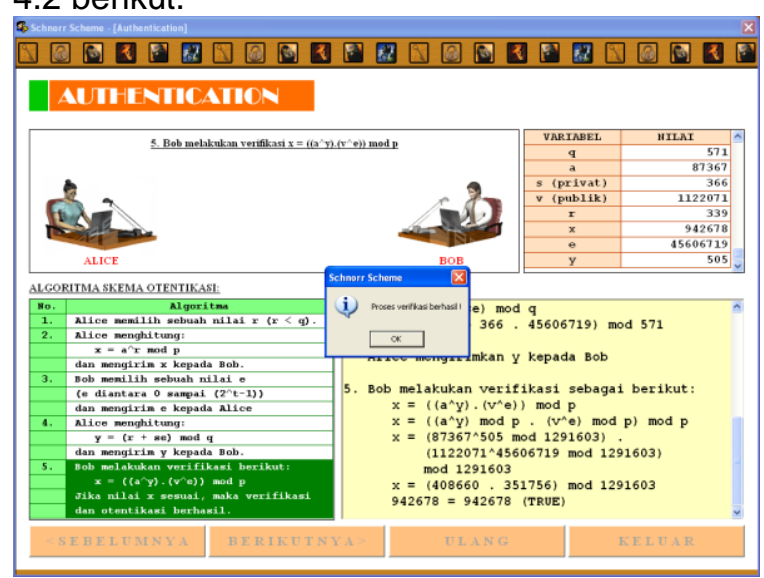

Gambar 4.2 Form Proses Otentikasi

(Authentication)

Prosedur yang dilakukan pada proses otentikasi adalah sebagai berikut:

1. Alice memilih nilai $r$ sebagai berikut: $r=339$

2. Alice menghitung nilai $x$ $x=a^{\wedge} r$ mod $p$ (selesaikan dengan fast exponentiation)

$\mathrm{x}=87367^{\wedge} 339 \bmod 1291603$

$\mathrm{x}=942678$

Alice mengirimkan $x$ kepada Bob

3. Bob memilih nilai e sebagai berikut: $e=45606719$

Bob mengirimkan e kepada Alice

4. Alice menghitung nilai y sebagai berikut:

$y=(r+s e) \bmod q$

$y=(339+366.45606719) \bmod 571$

$y=505$

Alice mengirimkan y kepada Bob

5. Bob melakukan verifikasi sebagai berikut:

$x=\left(\left(a^{\wedge} y\right) \cdot\left(v^{\wedge} e\right)\right) \bmod p$

$x=\left(\left(a^{\wedge} y\right) \bmod p \cdot\left(v^{\wedge} e\right) \bmod p\right) \bmod p$

$\mathrm{X}=\left(87367^{\wedge} 505 \mathrm{mod} 1291603\right)$.

(1122071^45606719 mod 1291603) $\bmod 1291603$

$\mathrm{x}=(408660$. 351756) $\bmod 1291603$

$942678=942678$ (TRUE)

Hasil perhitungan operasi $\left(\left(\left(a^{\wedge} y\right) \cdot\left(v^{\wedge} e\right)\right) \bmod p\right)$ sama dengan nilai $x$. Proses otentikasi berhasil.

3. Proses Tanda Tangan Digital (Digital Signature)

Form proses tanda tangan digital dapat dilihat pada gambar 4.3 berikut.

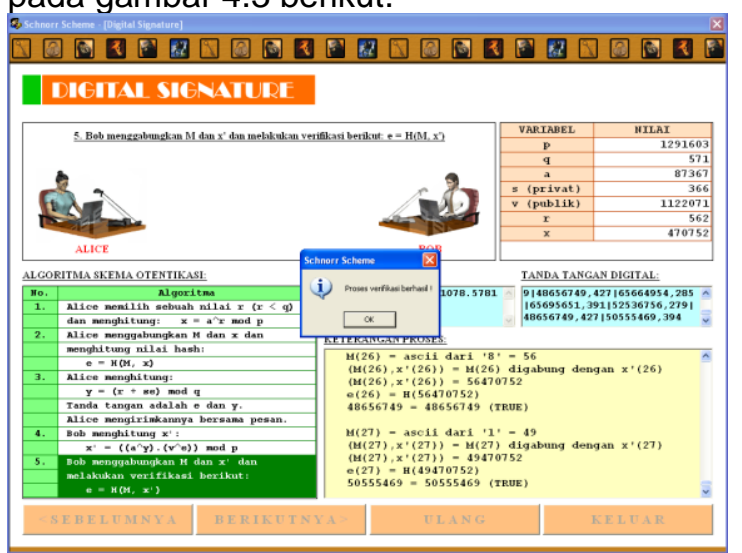

Gambar 4.3 Form Proses Tanda Tangan Digital (Digital Signature)

Misalkan pesan adalah 'No.rek bank = 125.1078.5781'.

Tanda tangan digital yang dihasilkan adalah: |57556954,397|65496769,88|65664954,285|6953 $4851,528|49506556,379| 50666569,371 \mid 66505766$ ,453|65655348,136|50685465,355|57666967,519| $50666569,371|66505766,453| 51674948,93 \mid 66505$ $766,453|50555469,394| 66565254,260 \mid 65695651$, $391|65664954,285| 50555469,394|56486751,108|$ $52536756,279|48656749,427| 65664954,285 \mid 6569$ $5651,391|52536756,279| 48656749,427 \mid 50555469$ ,394

\section{Kesimpulan}

Setelah menyelesaikan perangkat lunak simulasi Schnorr Authentication dan Digital Signature Scheme, penulis menarik kesimpulan sebagai berikut:

Penerapan Digital Signature Scheme Dengan Metode Schnorr Authentication 
1. Hasil rancangan perangkat lunak dapat membantu pemahaman terhadap skema Schnorr, baik skema otentikasi maupun skema tanda tangan digital. Perangkat lunak dapat digunakan untuk mendukung kegiatan belajar mengajar, terutama dalam mata kuliah Kriptografi.

2. Perangkat lunak juga menyediakan layar teori yang berisi dasar-dasar teori dari algoritmaalgoritma yang berada di dalam kedua skema Schnorr tersebut, sehingga dapat membantu pemahaman terhadap algoritma-algoritma tersebut.

\section{DAFTAR PUSTAKA}

[1] Schneier, B., Applied Crytography, Second Edition, John Willey \& Sons Inc., 1996.

[2] Kurniawan, J., Kriptografi, Keamanan Internet dan Jaringan Komunikasi, Informatika, Bandung, 2004.

[3] Munir, R., Kriptografi, Informatika, Bandung, 2006.

[4] Andi, Panduan Praktis Pemograman Visual Basic 6.0 Tingkat Lanjut, Wahana Komputer, Yogyakarta, 2004.

[5] Supardi, Y., Microsoft Visual Basic 6.0 Untuk Segala Tingkat, PT. Elex Media Komputindo, Jakarta, 2006.

[6] Novian, A., Panduan MS. Visual Basic 6, Andi, Yogyakarta, 2004. 